\title{
The Determinants of Voluntary Disclosure in Indonesia State-Owned Enterprises Annual Reports
}

\author{
Cory Fadila ${ }^{1}$ \\ Ministry of National Development Planning/Bappenas - Indonesia
}

\begin{abstract}
The purpose of this research is to investigate the determinants of voluntary disclosure in the annual reports of Indonesia State Owned Enterprise ("SOE”). A content analysis was applied to 60 SOEs' annual reports to assess the extent of SOEs voluntary disclosure, and Ordinary Least Squares ("OLS") regression was conducted to examine the relationship between explanatory variables and the extent of SOEs voluntary disclosure. The results show that SOEs disclose more about nonfinancial than strategic and financial information. There is also a high variability of SOEs voluntary disclosure indicated in the results. The study introduces a new variable, the priority programs, which represents the Government policy. This new variable appears to have a negative association with the extent of SOEs voluntary disclosure, while the firm size has a positive relationship. The study suggests that organisational legitimacy, company reputation and agency cost are the possible motivations for such disclosure behaviour. The regulator might places emphasis on the nonfinancial information disclosure and direct its attention to small SOEs to promote disclosure. Finally, further research may explore on who benefits the most from voluntary disclosure and how it could help them in making a better decision.
\end{abstract}

Keywords: voluntary disclosure, State Owned Enterprise.

\footnotetext{
${ }^{1}$ Cory Fadila is a Planning staff at the Bureau of General Affair, Ministry of National Development Planning/
} Bappenas. Email address: cory.fadila@bappenas 


\title{
The Determinants of Voluntary Disclosure in Indonesia State- Owned Enterprises Annual Reports
}

\author{
Cory Fadila
}

\section{Introduction}

The annual report has become a valuable communication tool for organisations because it has been used as the medium to communicate with the current and potential stakeholders (Barako et al., 2006). The stakeholders use the information disclosed in the annual report as a primary source for their decision making and effective control (Pablos et al., 2002). However, the dissatisfaction of mandatory financial reporting has led to the increasing need for a voluntary disclosure (Boesso and Kumar, 2007). Thus, the practice of companies voluntarily discloses additional information beyond the mandatory requirements become a regular business practice, nowadays. The factors influencing voluntary disclosure practice seems to be inconclusive as the results of previous studies assessing the determinants of voluntary disclosure are somewhat mixed (Boesso and Kumar, 2007). For example, some studies found that firm size is significantly related to the extent of voluntary disclosure ( Boesso and Kumar, 2007; Chau and Gray, 2002). However, Aljifri (2008) found that it is an insignificant variable. Wang et al. (2008) reported that state ownership has a positive relationship with the voluntary disclosure, while Ghazali and Weetman (2006) found no significant association. Wang et al. (2008) empirically proved that profitability is a significant variable, while Hossain and Hammami (2009) found an insignificant relationship with voluntary disclosure.

Previous researches on voluntary disclosure practice are heavily focused on the private sector and less in public sector (Laswad et al., 2005). The practice even has far remained largely unexplored in the SOE context (Ferguson et al., 2002). Accordingly, this study aims to examine the determinants of voluntary disclosure practice in Indonesia SOEs. As indicated earlier, prior studies yielded inconsistencies in some variables. However, there are certain common drivers of voluntary disclosure identified in the relevant literature. Therefore, this study uses the factors which have been employed in the previous studies. In addition to that determinants, a new variable, the priority programs, is introduced in this study to reflect the SOE context in Indonesia. A mixed approach of content analysis and OLS regression is utilised to achieve the objective of the research.

This study provides added value to current studies in a variety of ways. First, it contributes to the growing literature on disclosure practice by providing empirical evidence. Second, the introduction of new variable provides valuable insight into the wide ranging possible factors that could impact the disclosure practice. Finally, the research also offers the recommendations to the regulators in considering the appropriate regulations related to disclosure practice in SOE.

\section{Literature Review}

Watson et al. (2002, p. 289) define voluntary disclosure as 'disclosures in excess of those required by laws, accounting standards or stock exchange listing requirements 
regulations'. Various theories have been used to explain such practice amongst organisations. Legitimacy theory provides a perspective on explaining the voluntary disclosure practice. The theory has been used by many researchers to explain and predict particular management behaviour, including the decision to voluntarily disclose additional information. According to Deegan and Unerman (2011), legitimacy theory views that there is a strategy embedded in the accounting disclosure practice. They argue that corporations will keep ensuring that their operations are perceived as legitimate, that is to operate within the values and norms of the respective societies. Accordingly, they claim that an organisation will pursue legitimation strategies, including gaining, maintaining or repairing legitimacy, whenever its legitimacy is threatened. Signalling theory asserts that voluntary disclosure is a tool to solve the asymmetry information exists in the market (Hughes, 1986). The disclosure of information signals activities taken by the company. Investors are required to interpret and justify that information and act accordingly.

Deegan and Unerman (2011) agree that stakeholder theory is slightly similar to the legitimacy theory since it views the organisation as a part of the wider social system. However, legitimacy theory focuses on the expectations of society in general, while stakeholder theory emphasises particular stakeholder groups. There is a power issue embedded in the stakeholder theory that organisation will respond to particular group's expectations only if they have more power relative to others (Deegan and Unerman, 2011; Bailey et al., 2000). The organisation needs to prioritise and seek for the balance of, sometimes conflicting, interests of the influential stakeholders to ensure its business survival (Shankman, 1999). Failure to meet these important stakeholders will have an adverse impact on organisation's operation. Consequently, the decision to disclose information should be made carefully to address the expectations of those important stakeholders. Agency theory accepts that agent, who perform service on behalf of the principals, is a utility maximiser who does not always acting in the best interest of the principal (Zimmerman, 1977). Thus, monitoring and appropriate incentives are needed by the principal to limit the deviant of agent's behaviour (Jensen and Meckling, 1976). The agents are assumed to have more information compared to the principal, which could lead them to act opportunistically (Barako et al., 2006). Thus, the voluntary disclosure is used by the management to convince shareholder that they are acting optimally with the concern of the principal (Healy and Palepu, 2001). In addition to that, due to the separation of ownership and control, Jensen and Meckling (1976) argue that agents bear the bonding cost to ensure that their activities are appropriate with the principal interest. Accordingly, the agents are motivated to provide monitoring to reduce such bonding cost.

\subsection{SOE in Indonesia}

According to the Government of Republic Indonesia ("GOI") Regulation No. $45 / 2005$, SOE is an organisation which is owned wholly or at least $51 \%$ by the GOI. There are two types of SOE in Indonesia, which are the Limited Liability ("PT") and Public utility enterprises/special purpose entities ("Perum”). PT and Perum are different in structure and nature as stipulated in the Minister for SOE Regulation No. PER-01/MBU/2011. In 2015, there was a total of 123 SOEs consisting of 108 PT and 15 Perum. SOEs are managed by two shareholding ministers, the Minister for SOE and the Minister of Finance. Both of them hold the shares of SOE on behalf of the GOI. In the case SOE is wholly owned by GOI, the 
Ministers represent GOI as the General Meeting of Shareholders. In the meanwhile, GOI act as the shareholder when they own only part of the SOE shares.

In the recent years, there has been a considerable need for the SOE reform in Indonesia. Wicaksono (2008) argues that the need for better governance in SOE was triggered by the poor rank of SOE Good Corporate Governance (“GCG”) in various ratings, while on the other hand, it dominated the market capitalisation on the Jakarta Stock Exchange ( $40.23 \%$ of total market). Stricter regulations, such as a rule No. PER-01/MBU/2011 which regulates the implementation of GCG in SOE was then released in response to the demand for a more professional and transparent SOE. Disclosure and transparency are one of the GCG principles that is extensively promoted as part of SOE reform in Indonesia. Therefore, it is possible that the reform may have an impact on the SOE disclosure practice.

\subsection{Drivers of Voluntary Disclosure in Prior Studies}

Previous studies have investigated various determinants of the voluntary disclosure. However, Barako et al. (2006) suggest that there is no ultimate prescription to explain the practice because the empirical findings of the studies are somewhat inconclusive. They acknowledge that there are three main themes associated with the drivers of voluntary disclosure, which are firm characteristics, ownership structure and corporate governance. Hossain et al. (1995) examined empirically the relationship between five firm characteristics, namely firm size, leverage, total assets, auditor type, and foreign listing status, with the general level of voluntary disclosure of companies listed in New York Stock Exchange. Previous studies have also considerably studied the association between ownership structure and voluntary disclosure practice. Chau and Gray (2002) examined the influence of ownership structure and voluntary disclosure. They found that family-controlled companies in Hong Kong and Singapore are less motivated to disclose additional information voluntarily. Many studies have used the board composition as the proxy for corporate governance, for example, Eng and Mak (2003), Haniffa and Cooke (2002), Chen and Jaggi (2000). Eng and Mak (2003) found that the existence of outside non-executive directors in the board affect the voluntary disclosure negatively. The study of disclosure related literature reveals that voluntary disclosure practice is dynamic. The motivations and determinants of the voluntary disclosure may vary in a different setting. The issue is that there is a lack of concern on studying the disclosure behaviour in SOE context. Thus, an empirical research will be implemented to get more understanding of the voluntary disclosure practice in SOE.

\subsection{Hypotheses Development}

The research investigates the determinants of voluntary disclosure that are commonly used by previous studies, including firm size, profitability, industry type, type of auditor, independent commissioners, government ownership and the priority programs. Agency theory asserts that bigger company requires higher monitoring cost (Jensen and Meckling, 1976). Thus, management is encouraged to disclose more information to reduce such monitoring cost voluntarily. This condition may also be applicable within the SOE context in Indonesia. Since the GOI owns at least $51 \%$ of the ownership at SOE, the bigger SOE means that the larger portion of the public money that is managed by the SOE. Accordingly, a greater monitoring might be required by the public. A higher monitoring could lead to a higher 
agency cost. Thus, it is expected that $\mathrm{SOE}$ to disclose more information to reduce such cost. Based on signalling theory, Ousama et al. (2012) argue that voluntary disclosure is used by profitable companies to signal their better position in the market. Profitable SOEs might also be expected to voluntarily disclose more information to show their position in the market and to compete with the non-SOE firms. Utama and Utama (2012) suggest that regulated industries are more likely to disclose additional information because the regulatory bodies require them to be more transparent and, thus, encourage them to provide more information disclosure. The high visibility of SOE as a public company makes those SOEs which engaged in the regulated industries to be expected to provide even more information. Signalling theory claims that company takes some actions to signal information to the market. Datar et al. (1991) argue that the high-quality auditors require a high standard quality of disclosure and earning performance, and it consequently provides positive signals about the firm's value to the market. Also, Premuroso and Bhattacharya (2008) suggest that the Big Four firms encourage its clients to provide a higher transparency and disclosure, to maintain their good reputation in public.

Agency theory accepts that the separation of ownership and management requires the principal to monitor the likelihood of the agent's opportunistic behaviour. Chau and Gray (2010) argue that the existence of independent director is likely to result in more effective monitoring of management behaviour. Accordingly, management is encouraged to provide more information, in response to the increased monitoring. In the case of SOE in Indonesia, the appointment of an independent director is unfamiliar. However, the Minister for SOE rule no. PER-01/MBU/2011 requires SOE to have at least a proportion of $20 \%$ independent commissioners. This independent commissioner has a similar main duty with the independent director, which is to supervise the Board of Director ("BOD") to work in the best interest of the shareholders. Within the lens of agency theory, Eng and Mak (2003) argue that the conflicting objectives between profit seeking and public service of the SOE lead to a higher agency cost in such companies. Accordingly, the agent is encouraged to provide better communication with their stakeholders through disclosing more information. Further, Alfraih and Almutawa (2017) suggest that within the legitimacy theory, firms with high government ownership is predicted to disclose additional information because their activities are monitored by the public. This condition may also be applicable in Indonesia SOE because of the relatively high (at least 51\%) ownership by the GOI.

The research introduces a new variable, which is the priority programs. This variable has never been examined by prior studies. However, it was developed based on the previous studies, including Zimmerman (1977), Baber (1983), Pablos, et al. (2002) and Laswad, et al. (2005). Zimmerman (1977) suggests that the agency problem exists in the government context between the voters (principal) and the elected officials (agent/politician). He further argues that agent's welfare maximisation depends on the likelihood of re-election, while principal's welfare is tied to the agent's actions. Baber (1983) acknowledges that if the politician wishes to be elected, they cannot ignore the pre-election promises. Thus, he further suggests that to demonstrate that they are fulfilling the pre-election promises, elected officials will supply monitoring. Pablos et al. (2002) argue that financial disclosure can be considered as an essential tool for the voter to monitor and prevent the elected officials from behaving opportunistically. Laswad et al. (2005) indicate that managers in public sector are motivated 
to disclose information to allow monitoring on their actions voluntarily. The discussion above suggests that the role of the financial disclosure can be viewed in two ways. First, it is used by the voters to monitor the elected officials' behaviour. Second, it is utilised by the elected officials to show that they are honouring the pre-election promises.

The incumbent president of the Republic of Indonesia was elected in 2014 through a tough competition, by winning $53.15 \%$ of total votes. The President formalised his preelection promises as the national development agenda, called Nawa Cita. It comprises of nine development programs which were translated into the 2015-2019 National Mid-Term Development Plan (“RPJMN") and annual Government Working Plan (“RKP”). The RKP details the RPJMN into priority programs specifying the programs, target, budget and the responsible party for each program. SOE as one of the development agent is expected to take a significant role to support the achievement of Nawa Cita. Accordingly, a substantial increase of State Capital Investment (Penyertaan Modal Negara) was provided to some SOEs to support the priority programs, from a total of Indonesian Rupiah ("IDR") 7.3 billion in the state budget for the year 2015 to IDR 67.67 billion in the revised state budget for the year 2015. The association between the priority programs with the extent of voluntary disclosure in SOEs can be explained by two theoretical perspectives. Dowling and Pfeffer (1975) argue that legitimacy will affect the SOE because its existence highly depends on social and political support. The priority programs represent the Government policy that derived from the President pre-election promises. It is politically exposed and widely impacts the society. Accordingly, organisational legitimacy may become more important for SOEs engaged in those programs. Cuadrado-Ballesteros et al. (2014) add that to gain, maintain and legitimise agreements to the population, entities, specifically the public sector, will use the voluntary disclosure. It suggests that SOEs may use voluntary disclosure to gain or maintain legitimacy. SOEs engaged in the priority programs may have higher social and political exposure. Therefore, they might put a greater emphasis on organisational legitimacy and thus, disclose more information. Within the lens of agency theory, SOEs are the Government arm's length that acts as agents. They are mandated by the GOI to execute the priority programs which is the translation of the President pre-election promises. Thus, SOEs that perform the priority programs might use voluntary disclosure to allow monitoring of the President pre-election promises execution.

\section{Methodology}

A combination of qualitative and quantitative approach was applied in the research. The application of mixed approach in this study is considered to be appropriate because the study not only seeks to confirm the determinants of SOEs voluntary disclosure but also to explore the extent of the voluntary disclosure and its possible motivations. Specifically, the study employed the sequential mixed design where the inferences made in the first phase become the basis for the question of the second strand (Tashakkori and Teddlie, 2003). First, as with previous studies (Boesso and Kumar, 2007; Ferguson et al., 2002; Chau and Gray, 2010), an initial content analysis was conducted to address the extent of SOEs voluntary disclosure by assigning a score to selected items disclosed in the annual report. These selected items are that information included in the disclosure index. The voluntary disclosure score yielded from the content analysis provides information about the range of 
voluntary disclosure in SOEs' annual reports. Next, the OLS regression was performed to examine the association between the voluntary disclosure score (dependent variable) and the independent variables, including the firm size, profitability, industry type, type of auditor, independent commissioner, government ownership and the priority programs. Finally, the content analysis and regression results corroborate with the study of literature, were used to explore the motivations for SOEs voluntary disclosure.

Bryman (2016, p.283) defines content analysis as 'an approach to the analysis of documents and texts (which may consist of words and images and may be printed or online, written or spoken) that seek to quantify content regarding predetermined categories and in a systematic and replicable manner. The study applied a partial form of content analysis because not the whole text was analysed but only the predetermined items of information included in the disclosure index (Beattiea, McInnes, \& Fearnley, 2004). Boesso and Kumar (2007) argue that content analysis involves subjectivity. Thus, as Bryman (2016) suggests, there are two qualities of content analysis that should be in place to reduce the subjective bias, including the transparency (objectivity) and systematic (consistent) procedure. The study established a coding schedule and manual to achieve those qualities. Coding schedule comprises of the list of information included in the disclosure index, while coding manual specifies the coding procedures. It is expected that the establishment of those instruments could reduce the personal research biases.

Chau and Gray (2002) argue that disclosure index not include all information disclosed by the companies. However, it comprises of important information disclosure that is expected to be disclosed in the annual reports. Thus, they suggest that disclosure index might be able to seize the significant degree of voluntary corporate disclosure. The initial disclosure index used in the study was based on the index developed by Gray et al. (1995) and Meek, et al. (1995). However, the index was tailored with the related Indonesia reporting regulations, such as Indonesia Financial Accounting Standards ("SAK") and the rules and the guidelines on financial statement presentation and disclosures issued by the Financial Services Authority ("OJK"). This modification was performed to eliminate the items that are considered as mandatory disclosure. The process yielded 65 preliminary checklists.

There are 17 additional items included in the index to incorporate the Indonesia SOE context. These items were gained from the Annual Report Awards ("ARA") criteria which have been used to assess the SOE's annual report in the ARA event. Those criteria were cross-checked with the related Indonesia reporting regulations to exclude the mandatory items. The final voluntary disclosure index used in the study consists of 82 items. Following the previous studies (Meek et al., 1995; Ferguson et al., 2002; Chau and Gray, 2010) the total disclosures were divided into three types of information, the strategic, financial and non-financial information. The reason for this division of information is because the factors affecting voluntary disclosure may vary by information types (Meek et al., 1995). Strategic and financial information have decision relevance to investors, while nonfinancial information is targeted the company's social accountability (Chau and Gray, 2010). This study uses an unweighted disclosure index to reduce the subjective assessment (Cooke, 1989). The unweighted disclosure index assumes an equal importance of each item of disclosure (Gray, Meek, \& Roberts, 1995), although the information content may vary widely (Barros, Boubaker, \& Hamrouni, 2013). Cooke (1989) notes that the unweighted index is appropriate 
for the study that is not targeting a particular user group. Since this study is targeting all users of corporate annual reports, then it is believed that this unweighted disclosure index is appropriate.

A mention-based content analysis was conducted to examine the extent of voluntary disclosure. SOE received a score of one (1) if it mentions any of the items included in the index and zero (0) if it does not. As with Utama and Utama (2012) and Ousama et al. (2012), the disclosure score was obtained from the actual score divided by the maximum possible score. Therefore, SOEs will not be penalised by not disclosing information that is not relevant to them (Wang, O, \& Claiborne, 2008). However, when information is not included in the annual report, it becomes an issue to determine whether the information is not disclosed (0) or not applicable (N/A) (Chau and Gray, 2002). Thus, the not applicable (N/A) score was only be assigned to SOE after the whole annual report is examined and it is confirmed that there is no similar information found in the report (Chau and Gray, 2002). The assignment of (N/A) score was also be applied when it is explicitly stated in the annual report that particular information is not relevant to that particular SOE. An OLS regression was performed to examine the relationship between the extent of SOEs voluntary disclosure and the explanatory variables.

Considering the characteristic of the samples and following previous studies, such as Hossain et al., (1995) and Premuroso and Bhattacharya (2008), the study used the log of total assets as at 31 December 2015 as the proxy for firm size. The reason is that some of the samples are the non-listed SOEs. Thus the data on the market value of those company are not available. Moreover, not all SOEs reported its total asset in the local currency, the IDR. For comparability, a translation process was performed for SOEs which total asset is denominated in foreign currencies by using the BI Middle rate as at 31 December 2015 (1 USD equals to IDR 13,795). The Return on Equity ("ROE") was used as the proxy of the profitability. The ROE was calculated by dividing net income as per 31 December 2015 by the average shareholder equity. This approach is consistent with Ousama et al. (2012). Industry type is a dummy variable. SOE was coded one (1) if they engage on regulated industries, while coded zero (0) if they do not belong to regulated industries. In Indonesia, banking and finance industry is considered to be more regulated than other sectors. Both banking and financial sector is regulated and monitored by OJK. As with Utama and Utama (2012), the regulated industries include the bank, financial institution, security companies, insurance, investment fund/mutual fund and other financial institutions.

Type of auditor is a dummy variable. SOE was coded one (1) if they are audited by the Big-Four (PwC, KPMG, Deloitte, EY) and zero (0) if otherwise. Premuroso and Bhattacharya (2008) argue that there are many types of corporate governance proxies available in the literature, such as corporate governance score and board composition. However, the study used the board structure as the proxy for corporate governance because the assessment of corporate governance implementation in SOE is not conducted annually. Thus, some SOEs may not have such information for the observed year. The study used the independent commissioner composition as the proxy because the appointment of an independent director is unfamiliar in Indonesia SOE. Independent commissioner composition was measured by the ratio between the total independent commissioner and the entire Board of Commissioners member. Following Eng and Mak (2003), the government ownership was measured by the 
percentage of Government share ownership in the SOE as at 31 December 2015. Priority programs is a dummy variable. According to the financial notes and revised state budget of Indonesia for the year 2015, the priority programs that were supported by SOE include the maritime development programs, security and defence industry programs, infrastructure development and connectivity programs, food resilience programs and national economic sovereignty. Based on the Ministry for SOE strategic planning document 2015-2019, SOE is categorised into 15 sectors. A mapping process was then conducted to match the categorisation of SOE with the priority sectors. SOE was coded one (1) if it matched with any of the priority sectors and coded zero $(0)$ if otherwise.

Applying the OLS regression, the following model was estimated:

$$
\begin{aligned}
& \text { Dscore }=\alpha+\beta_{1} \text { Fsize }+\beta_{2} \text { Prof }+\beta_{3} \text { IndsType }+\beta_{4} \text { TypeAud }+\beta_{5} \text { IndCo } \\
& +\beta_{6} \text { GovOwn }+\beta_{7} \text { Priority }+e \quad \text { (equation } 1 \text { ) }
\end{aligned}
$$

As with Wang, et al. (2008), the equation above was replicated to each voluntary disclosure score partitioned into strategic (equation 2), nonfinancial (equation 3) and financial information (equation 4) to assess the effects of different types of disclosure. The population of the study comprises of PT and Perum. However, due to the major differences between PT and Perum, the study focuses only on the limited liability SOEs. The reason is to ensure the comparability of the samples in which they are homogeneous. PT represents $88 \%$ of total SOE population. The initial sample of the study was 108 SOEs, but it was reduced to 60 SOEs because 45 of them did not publish its annual report on its website and some data were missing from three SOEs. The study used the secondary data, which is the published annual reports for the year 2015. These reports were collected from the SOE's official websites. In addition to the annual report, data was also gathered from the government documents which were published on the Government's official websites.

\section{Results and Analysis}

The OLS assumption tests show that the residuals are normally distributed, and there is no heteroscedasticity in the OLS model. The covariance matrix also shows that there is no sign of perfect collinearity between independent variables. Thus, the OLS model specified in the study generates an unbiased estimation. The descriptive statistics indicates that SOEs' average profitability is low. This small mean of profitability might be due to the two samples experienced loss in 2015. The industry type of 0.32 indicates that majority of the samples are not engaged in regulated industry, while the type of auditor mean of 0.38 shows that most of the samples are not audited by the Big Four audit firms. The independent commissioner composition mean of $23.42 \%$ suggests that majority of the sample firms complied with the minimum of $20 \%$ independent commissioners rule. The government ownership shows a high average of $86.90 \%$ which implies that most of the samples are highly owned by the GOI. Similarly, the relatively high average of the priority programs of 0.58 indicates that most of the sample firms are engaged in the priority programs. The results reveals that the extent of total SOEs voluntary disclosure varies considerably, ranging from 0.08 to 0.54 . The disclosure score varies considerably on the nonfinancial information and fairly variable for the strategic information. However, it is not the case for the financial information. The low variability of financial information disclosure (0 to 0.08$)$ may infer that there is conformity amongst SOEs 
on the importance of disclosing or not disclosing such information.

The result shows that the average of nonfinancial information disclosure is the highest compared to the remaining two types of information. Three reasons may explain this phenomenon. First, $43 \%$ of total items included in the disclosure index is the nonfinancial related items. Thus, it is by design that the nonfinancial information has a greater opportunity to be scored. Second, during the coding process, it was noted that most of the SOEs prepared its annual report based on the ARA criteria. Since $65 \%$ of the additional index are the nonfinancial items derived from ARA criteria, then it is possible that this type of information to get a higher score. Third, Meek et al. (1995) suggest that nonfinancial information is targeted a wider stakeholder beyond investor group. Luke (2010) adds that SOE has extended lines of ownership and accountabilities, which includes managerial (e.g., central government, BOD), political (e.g., ministers, opposition parties), public (e.g., a taxpayer, citizen, voters), professional and legal. Accordingly, it seems logical that SOEs to disclose more about nonfinancial information because they may want to accommodate the expectations of those extended stakeholders.

The result shows that none of the variables exhibits pairwise correlations over 56 per cent. This value is lower than the threshold value of 0.80 which has been used by some researchers (Halcoussis, 2005). Thus, multicollinearity does not present a serious concern in the study. However, to further examine the potential for multicollinearity, the test on the robustness of the model was performed, including the Variance Inflation Factor ("VIF") and the tolerance value. In this study, the tolerance levels for all variables are above 0.6 , and no independent variables have VIF value above 1.7. It suggests that multicollinearity is unlikely to pose a serious problem in the interpretation of the study's multivariate analysis results.

The result exhibits that the regression model Equation 1,2 and 4 are statistically significant at 95\%, 99\% and 95\% confidence level, respectively. The adjusted Coefficient of Determination ("R square") of Equation 1 equals to 0.155 . It suggests that the model explains $15.5 \%$ of the association between the extent of SOEs voluntary disclosure and the explanatory variables. This low R square indicates that there are might be any other possible variables ignored in this model. Equation 3 appears to be not a significant model. The insignificant association between non-financial information disclosure and the independent variables may also relate to the extended ownership and accountability of SOE which may have an impact on the diversity of factors that may influence the decision to disclose nonfinancial information. Thus, Equation 3 may not adequate to capture the variety of possible determinants that could influence SOE in disclosing nonfinancial information.

The result reveals that firm size is a significant determinant of total voluntary disclosure on SOEs annual report with $90 \%$ confidence level. This finding also supports the prediction of agency theory that total voluntary disclosure increases with a greater firm size. Singhvi and Desai (1971) suggest that there are three reasons for large enterprises to disclose more information. First, the relatively low cost of providing detailed information for big firms. Second, the benefit gained from information disclosure, such as easier access to market and financing. Third, the belief that information disclosure would not endanger the competitive position of the big firms. For the context of SOE in Indonesia, the most applicable reason is related to the cost of disclosing information. Most of big SOEs have more developed information technology ("IT") systems applied within the company. This IT system processes 
and provides integrated data and information within the company on a timely basis. The availability of such system help reduces the cost of information production per unit (Cooke, 1989). Thus, it may not be a costly affair to them to provide additional information.

Profitability is not significantly related to total voluntary disclosure and to disclosure by information type. One possible reason for this is because most of SOEs in Indonesia operate in industries which are deemed by the GOI to be of strategic importance, such as electricity, oil and gas and public transport. Therefore, signalling a better position in the market may not be relevant to them as they may shielded from competition. Consequently, profitable SOEs are not motivated to voluntarily disclose additional information. The result reveals that industry type does not have a significant relationship with the extent of total voluntary disclosure. One possible reason for this insignificant result is because most SOEs, regardless its type of industry, refer to the same disclosure guidelines, the ARA criteria, in preparing the annual report. Accordingly, type of industry may become irrelevant to the total voluntary disclosure. Empirically, the type of auditor is not significantly related to both total voluntary disclosure and to disclosure by information type. However, it shows a positive sign as expected by signalling theory. In Indonesia, the external auditor primary reference in providing audit opinion is the SAK. Since the Big 4 accounting firms focus more on the compliant with the SAK than other rules, then it is possible that they pay attention to other reporting rules not more than other accounting firms.

The result exhibits that the composition of independent commissioner is not statistically significant to the extent of total voluntary disclosure although it shows a positive relationship. However, independent commissioner composition is a significant determinant for the financial information disclosure at $90 \%$ confidence level. This might due to one of independent commissioner' primary duty is to ensure the transparency of financial information. Therefore, it seems logical that SOE will disclose more financial information when the proportion of independent commissioner increases. State ownership is not significantly related to total voluntary disclosure and disclosure by information type. One possible reason for this is that the GOI ownership in all SOEs are relatively high (at least $51 \%)$. Thus, they might be exposed to the same degree of public scrutiny, which in turn, influence their disclosure behaviour similarly. The OLS regression reveals an interesting result that priority programs is negatively significant to the extent of total voluntary disclosure at $90 \%$ confidence level. There are three possible answers for this issue. First, according to RPJMN 2015-2019, the priority programs are executed through the synergy amongst SOEs. For example, the development of special economic zone Sei Mangke in North Sumatera which involve the collaboration of six SOEs (PT PLN, PT Pertamina Gas, PT Perusahaan Gas Negara Tbk, PT Perkebunan Nusantara III, PT Inalum, and PT Bukit Asam Tbk). This collaborative work makes it possible for SOE to less disclose information because it might be difficult to precisely identify who is responsible for different aspects of information. Second, in Indonesia, there is a non-structural institution that responsible and reports directly to the President, namely Kantor Staf Presiden ("KSP"). Based on Presiden regulation No. $26 / 2015$, the primary responsibility of KSP is to manage and monitor the implementation of the priority programs. Accordingly, the SOEs which involved in priority programs may not need to provide extensive disclosure because of such separate monitoring by the Government (Ghazali and Weetman, 2006). Third, Ghazali and Weetman (2006) further argue that SOEs in 
developing countries are likely to have strong political affiliations and, thus, they may disclose less information to protect political linkages. Faccio (2006) defines the politically connected firm as the company which one of its shareholder or top management is closely related to senior officials. Ombudsman Republik Indonesia (2017), an organisation who responsible to monitor the public service implementation, found that $41 \%$ of total commissioners in SOEs also work as a public officials. Accordingly, there is a potential existence of political affiliations in Indonesia SOEs. In the presence of political connection, it seems logical that SOE with higher social exposure might disclose less information to protect the political linkages that may exists within the company.

The content analysis and OLS regression results provide insights into the possible motivations for SOEs voluntary disclosure practice. The content analysis reveals that nonfinancial information has the highest average disclosure score compared to strategic and financial information disclosure. The emphasis on nonfinancial information disclosure could be interpreted that social support is critical to SOE's survival. The importance of social acceptance to the SOE's continuity might trigger the disclosure of additional nonfinancial information to maintain its legitimacy. Another motivation that could be drawn is that the use of ARA criteria as the guidelines for preparing the annual report in most SOEs indicates that they are motivated to create a good reputation through an award winning. This reason is consistent with Deegan and Carol (1993) who argue that winning an award may have a positive impact on company reputation. The regression results indicate that the firm size is a significant determinant to the extent of SOEs voluntary disclosure. Within the agency theory, the big companies are expected to disclose additional information to reduce agency costs. Luke (2010) notes that government ownership is often viewed and interpreted as public ownership. Such public perception implies that the big SOEs are perceived to control or manage a larger portion of the public money. It then possibly leads to a higher public monitoring for big SOEs. Accordingly, they might disclose more information than the small SOEs to reduce agency cost which occurs due to the increased public monitoring. In contrast, the results show that priority programs have a significant negative relationship with the extent of voluntary disclosure. The possible reasons for that phenomenon are due to shared responsibility, separate monitoring and political affiliations. It seems logical that SOEs are unlikely to disclose additional information to avoid negative image due to providing incomplete information and having political affiliations.

\section{Conclusion and Recommendation}

The study is aimed to investigate the determinants of voluntary disclosure in Indonesia SOEs annual reports for the year 2015. The content analysis result shows that there is a considerable variability of the SOEs voluntary disclosure. Compared to the other types of information, SOEs are likely to disclose additional nonfinancial information. Within the legitimacy theory, the higher disclosure of nonfinancial information could be interpreted that the social acceptance is crucial to SOE's survival. The regression results reveal that the firm size and priority programs are the significant determinants of the extent of total SOEs voluntary disclosure. The organisational legitimacy, reputation and agency cost are the possible motivations for SOEs voluntary disclosure drawn from the study. It may infer that firms use voluntary disclosure because of the good impact that it may bring to the organisation. 
There are three implications identified in the study. First, the higher proportion of nonfinancial information in the disclosure index and the greater disclosure of this type of information by SOEs imply that the regulator concerns more on regulating the financial and strategic information disclosure. Provided that the SOE not be only accountable for the investor but also to wider society, then the authorities might direct its attention to the regulation of nonfinancial information disclosure. Second, the regulator might places emphasis on promoting disclosure on small businesses. Also, the investor of the priority programs related SOEs might rely on other sources than annual report in obtaining information. Third, it is suggested that regulator enact the sanction enforcement for publishing the annual report to promote greater transparency in SOE.

\section{References}

Adams, C. A., \& Harte, G. (1998). The Changing Potrayal of the Employement of Women in British Banks' and Retail companies' Corporate Annual Report. Accounting, Organizatiotrsa and Society, 781-812.

Alberti-Alhtaybat, L. v., Hutaibat, K., \& Al-Htaybat, K. (2012). Mapping Corporate Disclosure Theories. Journal of Financial Reporting and Accounting, 10(1), 73 - 94.

Alfraih, M. M., \& Almutawa, A. M. (2017). Voluntary disclosure and corporate governance: empirical evidence from Kuwait. International Journal of Law and Management, 59(2), 217-236.

Aljifri, K. (2008). Annual report disclosure in a developing country: The case of the UAE. Advances in Accounting, incorporating Advances in International Accounting, 24, 93-100.

Baber, W. R. (1983). Toward Understanding The Role OF Auditing In The Public Sector. Journal of Accounting and Economics, 5, 213 - 227.

Bailey, D., Harte, G., \& Sugden, R. (2000). Corporate disclosure and the deregulation of international investment. Accounting, Auditing \& Accountability Journal, 13(2), 197-218.

Barako, D. G., Hancock, P., \& Izan, H. Y. (2006). Factors Influencing Voluntary Corporate Disclosure by Kenyan Companies. Journal compilation, 14(2).

Barros, C. P., Boubaker, S., \& Hamrouni, A. (2013, March/April). Corporate Governance and Voluntary Disclosure in France. Journal of Applied Business Research, 29(2), 561.

Beattie, V., \& Thomson, S. J. (2007). Lifting the lid on the use of content analysis to investigate intellectual capital disclosures. Accounting Forum, 129-163.

Beattiea, V., McInnes, B., \& Fearnley, S. (2004). A methodology for analysing and evaluating narratives in annual reports: a comprehensive descriptive profile and metrics for disclosure quality attributes. Accounting Forum, 205-236.

Boesso, G., \& Kumar, K. (2007). Drivers of corporate voluntary disclosure: A framework and empirical evidence from Italy and the United States. Accounting, Auditing \& Accountability Journal, 20(2), 269 - 296.

Bozzolan, S., Favotto, F., \& Ricceri, F. (2003). Italian annual intellectual capital disclosure: An empirical analysis. Journal of Intellectual Capital, 4(4), 543-558.

Bryman, A. (2016). Social Research Methods. Oxford: Oxford University Press.

Camfferman, K., \& E.Cooke, T. (2002). An Analysis of DIsclosure in the Annual Reports of U.K. and Ducth Companies. Journal of International Accounting Research, 1, 3-30.

Chau, G. K., \& Gray, S. J. (2002). Ownership structure and corporate voluntary disclosure 
in Hong Kong and Singapore. The International Journal of Accounting, 37, 247-265.

Chau, G., \& Gray, S. J. (2010). Family ownership, board independence and voluntary disclosure: Evidence from Hong Kong. Journal of International Accounting, Auditing and Taxation, 19, 93-109.

Chen, C. J., \& Jaggi, B. (2000). Association between independent non- executive directors, family control and ${ }^{\circledR}$ nancial disclosures in Hong Kong. Journal of Accounting and Public Policy, 19, 285 \pm 310.

Cooke, T. E. (1989). Voluntary Corporate Disclosure by Swedish Companies. Journal of Intemational Financial Management and Accounting, 1(2).

Cormier, D., \& Gordon, I. M. (2001). An examination of social and environmental reporting strategies. Accounting, Auditing \& Accountability Journal, 14(5), 587-617.

Creswell, J. W., Clark, V. L., Gutmann, M. L., \& Hanson, W. E. (2003). Advanced Mixed Methods Research Designs. Dalam A. Tashakkori, \& C. Teddlie (Penyunt.), Handbook of Mixed Methods in Social \& Behavioral research (hal. 228). California: Sage Publications, Inc.

Cuadrado-Ballesteros, B., 1as-Aceituno, J. ., \& inez-Ferrero, J. M. (2014). The role of media pressure on the disclosure of sustainability information by local governments. Online Information Review, 38(1), 114-135.

Datar, S. M., Feltham, G. A., \& Hughes, J. S. (1991). The Role of Audits and Audit Quality in Valuing New Issues. Journal of Accounting and Economics, 14, 3-49.

Deegan, C. (2002). Introduction: The legitimising effect of social and environmental disclosures - a theoretical foundation. Accounting, Auditing \& Accountability Journal, 15(3), $282-311$.

Deegan, C. (2002). The Legitimising Effect of Social and Environmental Disclosure - A Theoretical Foundation. Acounting, Auditing \& Acountability Journal, 15(3), 282 - 311.

Deegan, C., \& Blomquist, C. (2006). Stakeholder inXuence on corporate reporting: An exploration of the interaction between WWF-Australia and the Australian minerals industry. Accounting, Organizations and Society, 31, 343-372.

Deegan, C., \& Unerman, J. (2011). Financial Accounting Theory (Second European Edition ed.). Berkshire: McGraw-Hill Education.

Dowling, J., \& Pfeffer, J. (1975). Organizational Legitimacy: Social Values and Organizational Behavior. The Pacific Sociological Review, 18(1), 122-136.

Eng, L., \& Mak, Y. (2003). Corporate governance and voluntary disclosure. Journal of Accounting and Public Policy, 22, 325-345.

Faccio, M. (2006). Politically Connected Firms. The American Economic Review.

Ferguson, M. J., Lam, K. C., \& Lee, G. M. (2002). Voluntary Disclosure by State-owned Enterprises Listed on the Stock Exchange of Hong Kong. Journal of International Financial Management and Accounting, 13(2).

Financial Services Authority. (2012). Regulation No. KEP-431/BL/2012 Penyampaian Laporan Tahunan Emiten atau Perusahaan Publik.

Financial Services Authority. (2012). Regulation No. KEP-347/BL/2012 Penyajian dan Pengungkapan Laporan Keuangan Emiten atau Perusahaan Publk.

Frost, G. R., \& Seamer, M. (2002). Adoption of Environmental Reporting and Management Practices: An Analysis of New South Wales Public Sector Entities . Financial Ac- 
countability \& Management, 18(2), 0267-4424.

Ghazali, N. A., \& Weetman, P. (2006). Perpetuating traditional influences: Voluntary disclosure in Malaysia following the economic crisis. Journal of International Accounting, Auditing and Taxation, 15, 226-248.

Government of Republic of Indonesia. (2005). Regulation No. 45/2005 PENDIRIAN, PENGURUSAN, PENGAWASAN DAN PEMBUBARAN BADAN USAHA MILIK NEGARA .

Gray, R., Kouhy, R., \& Lavers, S. (1995). Corporate social and environmental reporting: a review of the literature and a longitudinal study of UK disclosure. Accounting, Auditing \& Accountability Journal, 8(2), 47 - 77.

Gray, S. J., Meek, G. K., \& Roberts, C. B. (1995). International Capital Market Pressures and Voluntary Annual Report Disclosures by U.S. and U.K. Multinationals. Journal of International Financial Management and Accounting, 6(1).

Hair, J. F., Black, W. C., Babin, B. J., \& Anderson, R. E. (2014). Multivariate Data Analysis (Seventh Edition ed.). Essex: Pearson Education Limited.

Halcoussis, D. (2005). Understanding Econometrics. Ohio: South-Western.

Hamrouni, A., Miloudi, A., \& Benkraiem, R. (2015). Signaling Firm Performance Through Corporate Voluntary Disclosure. The Journal of Applied Business Research, 31(2).

Hassan, O., \& Marston, C. (2010, July). Disclosure measurement in the empirical accounting literature - a review. London.

Healy, P. M., \& Palepu, K. G. (2001). Information asymmetry, corporate disclosure, and the capital markets: A review of the empirical disclosure literature. Journal of Accounting and Economics, 31, 405-440.

Herawaty, M., \& Hoque, Z. (2007). Disclosure in the annual reports of Australian government departments: A research note. Journal of Accounting \& Organizational Change, 3(2), $147-168$.

Hines, R. D. (1988). Financial Accounting: In Communicating Reality, We Construct Reality. Accounting, Organisation and Society, 13(3), 251-261.

Hossain, M., \& Hammami, H. (2009). Voluntary disclosure in the annual reports of an emerging country: The case of Qatar. Advances in Accounting, incorporating Advances in International Accounting, 25, 255-265.

Hossain, M., \& Reaz, M. (2007). The Determinants and Characteristics of Voluntary Disclosure by Indian Banking Companies. Corporate Social Responsibility and Environmental Management, 14, 274-288.

Hossain, M., Perera, M. H., \& Rahman, A. R. (1995). Voluntary Disclosure in the Annual Reports of New Zealand Companies. Journal of tntemational Financial Management and Accounting , 6(1).

Huafang, X., \& Jianguo, Y. (2007). Ownership structure, board composition and corporate voluntary disclosure: Evidence from listed companies in China. Managerial Auditing Journal, 22(6), 604-619.

Hughes, P. J. (1986). Signalling by Direct Disclosure under Asymmetric Information. Journal of Accounting and Economics , 8, 119-142.

IASB. (2015). Conceptual Framework for Financial Reporting. London: IFRS Foundation Publications Department. 
IPSASB. (2014). The Conceptual Framework For General Purpose Financial Reporting By Public Sector Entities. New York: The International Federation of Accountants.

Islam, M. A., \& Deegan, C. (2008). Motivations for an organisation within a developing country to report social responsibility information: Evidence from Bangladesh. Accounting, Auditing \& Accountability Journal , 21(6), 850-874.

Jensen, M. C., \& Meckling, W. H. (1976). Theory of the Firm: Managerial Behavior, Agency Costs and Ownership Structure. Journal of Financial Economics, 3, 305-360.

Khlif, H., \& Souissi, M. (2010). The determinants of corporate disclosure: a meta-analysis. International Journal of Accounting and Information Management, 18(3), 198-219.

Laswad, F., Fisher, R., \& Oyelere, P. (2005). Determinants of voluntary Internet financial reporting by local government authorities. Journal of Accounting and Public Policy, 24, 101-121.

Lim, S., \& McKinnon, J. (1993). Voluntary Disclosure by NSW Statutory Authorities: The Influence of Political Visibility. Journal of Accounting and Public Policy, 12, 189-216.

Luke, B. (2010). Examining Accountability Dimensions in State-Owned Enterprises. Financial Accountability \& Management, 26(2), 0267-4424.

LUKE, B. L. (t.thn.).

Magness, V. (2006). Strategic posture, financial performance and environmental disclosure: An empirical test of legitimacy theory. Accounting, Auditing \& Accountability Journal, 19(4), 540-563.

Meek, G. K., Roberts, C. B., \& Gray, S. J. (1995). Factors Influencing Voluntary Annual Report Disclosures by U.S., U.K. and Continental European Multinational Corporations. Journal of International Business Studies, 26(3), 561.

Naser, K., Al-Hussaini, A., Al-Kwari, D., \& Nuseibeh, R. (2006). Determinants of Corporate Social Disclosure in Developing Countries: The Case of Qatar. Advances in International Accounting, 19, 1-23.

O'Donovan, G. (2002). Environmental disclosures in the annual report: Extending the applicability and predictive power of legitimacy theory. Accounting, Auditing \& Accountability Journal, 15(3), 344-371.

Ombudsman Republik Indonesia. (2017, August). Diambil kembali dari http://www.ombudsman.go.id/index.php/berita/berita/siaran-pers-ombudsman/2321-siaran-pers-polemik-rangkap-jabatan,-ombudsman-ri-beri-solusi-kepada-pemerintah.html

Ousama, A. A., Fatima, A.-H., \& Hafiz-Majdi, A. R. (2012). Determinants of intellectual capital reporting: Evidence from annual reports of Malaysian listed companies. Journal of Accounting in Emerging Economies , 2(2), 119 - 139.

Pablos, J. L., Carcaba, A., \& Lopez, A. (2002). The annual report as a tool for financial disclosure in local governments. International Journal of Management, 19(4), 651.

Premuroso, R. F., \& Bhattacharya, S. (2008). Do early and voluntary filers of financial information in XBRL format signal superior corporate governance and operating performance? International Journal of Accounting Information Systems, 9, 1-20.

Ross, S. A. (1977). The Determination of Financial Structure: The Incentive-Signalling Approach. The Bell Journal of Economics, 8(1), 23-40.

Shankman, N. A. (1999). Reframing the Debate between Agency and Stakeholder Theories of the Firm. Journal of Business Ethics, 19(4), 319-334. 
Singhvi, S. S., \& Desai, H. B. (1971). An Empirical Analysis of the Quality of Corporate Financial Disclosure. The Accounting Review.

Tashakkori, A., \& Teddlie, C. (2003). Major Issue and Controversies in the Use of Mixed Methods in the Social and Behavioral Sciences. Dalam A. Tashakkori, C. Teddlie, A. Tashakkori, \& C. Teddlie (Penyunt.), Handbook of Mixed Methods in Social \& Behavioral Research (hal. 3). California: Sage Publications, Inc.

Tashakkori, A., \& Teddlie, C. (2003). The Past and Future of Mixed Methods Research: from Data Triangulation to Mixed Model Designs. Dalam A. Tashakkori, C. Teddlie, A. Tashakkori, \& C. Teddlie (Penyunt.), Handbook of Mixed Methods in Social \& Behavioral research (hal. 687). California: Sage Publications, Inc.

The Minister for State Owned Enterprises of Indonesia. (2011). Regulation No. PER - 01 /MBU/2011 PENERAPAN TATA KELOLA PERUSAHAAN YANG BAIK (GOOD CORPORATE GOVERNANCE) PADA BADAN USAHA MILIK NEGARA .

The Minister for State Owned Enterprises of Indonesia. (2014). Regulation No. PER-18/ MBU/10/2014 Penyampaian Data, Laporan, dan Dokumen Badan Usaha Milik Negara secara Elektronik.

The Ministry of National Development Planning of Indonesia. (2015). Rencana Pembangunan Jangka Menengah Nasional 2015 - 2019.

The President of Republic of Indonesia. (2015). Regulation No. 25/2015 Kantor Staf Presiden.

Tilt, C. A. (1994). The Influence of External Pressure Groups on Corporate Social Disclosure: Some. Accounting, Auditing \& Accountability Journal, 47-72.

Utama, C. A., \& Utama, S. (2012). Determinants of disclosure level of related party transactions in Indonesia. International Journal of Disclosure and Governance, 11(1), 74-98.

Verrecchia, R. E. (1983). Discretionary Disclosure. Journal of Accounting and Economics, 5, 179-194.

Wang, K., O, S., \& Claiborne, M. C. (2008). Determinants and consequences of voluntary disclosure in an emerging market: Evidence from China. Journal of International Accounting, Auditing and Taxation, 17, 14-30.

Watson, A., Shrives, P., \& Marston, C. (2002). VOLUNTARY DISCLOSURE OF ACCOUNTING RATIOS IN THE UK. British Accounting Review, 34, 289313.

Wicaksono, A. (2008). Indonesian State-Owned Enterprises: The Challenge of Reform. Southeast Asian Affairs, 146-167.

Williams, S. M. (2001). Is intellectual capital performance and disclosure practices related? Journal of Intellectual Capital, 2(3), 192-203.

Wilmshurst, T. D., \& Frost, G. R. (2000). Corporate environmental reporting: A test of legitimacy theory. Accounting, Auditing \& Accountability Journal, 13(1), 10-26.

Woodward, D. G., Edwards, P., \& Birkin, F. (1996). Organisational Legitimacy and Stakeholder Information Provision. British Journal of Management, 7, 329-347.

Xiao, J. Z., Yang, H., \& Chow, C. W. (2004). The determinants and characteristics of voluntary Internet-based disclosures by listed Chinese companies . Journal of Accounting and Public Policy, 23, 191 - 225.

Young, J. J. (2006). Making Up Users. Accounting, Organisation and Society, 31, 579-600.

Zimmerman, J. L. (1977). The Municipal Accounting Maze: An Analysis of Political Incentives. Journal of Accounting Research, 15, 107- 144. 